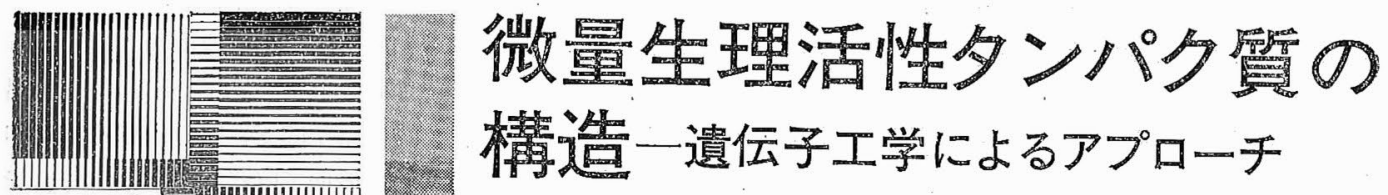

\section{1.は じめ.に}

生体にとって, 重要な役割を果たしている高分子一 特にタンパク質一の多くは，微量でしか存在しないた め, その単離・精製に浪多くの困難を伴う。したがっ て、これらを医潦薬剤として使用するに市たり，不可 欠である構造一活性部位なぞ一飞関する詳細な情報を 得ることが難しい, 一方, この数年, 発展の著しい遺 伝子工学の手法は，微量生体高分子をコードする“遗 伝子”を直接クローニングすることを可能视にしてき た.この結果, これらの生体高分子が大量にから, 純 粋な状態で得られるようになった。最近では，遺伝子 工学の手法により精製された物質を, 臨床的に使うこ とも可能になってきている，また，種々の疾患一敘状 赤血球貧血症, 自己免疫患など一の病因を, 遗伝子レ ベルで解析する試みもなされている.

本稿では, 遺伝子工学を用いて, どのように特定の 遗伝子をクローニングしていくのか，さらには，この 手法により得られた情報をどのように活用していくの か, 筆者らが研究しているとトの免疫応答遗伝子を例 にとりながら紹介する。

\section{2. 遺伝子のクローニングーヒトの 免疫応答遺伝子の場合}

\section{2-1. ヒトの免疫応答遺伝子の構造}

生体は, 免疫応答と総称される生体防御機構を通し て「自己」と「非自己」を識別している. この識別に 関与する分子の一つに「主要組織適合抗原. (MHC: Major Histocompatibility Complex)」が䍌る12,2). この $\mathrm{MHC}$ を支配する遺伝子は, 単一な遗伝子により 支配されているすのではなく, 近接して存在する数個 あるいはとれ以上の遗伝子座により支配されているこ とが明らかにされ "super-gene family" と称されて

Application of Genetic Engineering to Isolate Biologically Important Substances
いる.

ヒトに招いては, この抗原を支配する遺伝子群を 「HLA-複合体」と呼び，第 6 染色体上に位置している (図 $1 \mathrm{~A}$ )。この複合体は，之の遺伝子産物の特性より 3つのクラスに分けられ，艺れぞれクラスI，II怙よ び而と呼ばれている.クラスI分子をコードする遣伝 子座は，A，B扨よびC 領域から構成され，いわゆる 古典的な移植抗原である.クラス川分子をコードする 遺伝子座がD領域で, この領域はさらに 3 つ亚領域 飞細分化され，それぞれ，DR，DC および SB 西領 域*之呼ばれている。この領域に, 抗原に対して, 抗 体産生の有䎸を規定する遗伝子群 (immune response genes）が存在する. したがって，免疫応答を直接支 配する遗伝子の集まりといえる. 生化学的研究 ${ }^{12,2)}$ に より,この領域よりコードされる抗原は, 細胞膜に結 合した 2 つの糖タンパク質よりなり,それぞれ， $\alpha$ 鎖 (分子量 34,000$), \beta$ 鎖（分子量 29,000 ) と呼ばれて いる(図 1 B ). この “D領域” の遺伝子構造を明らか にすることは, 生体内で起こる複雑な“免疫応答機構” を分子レベルで理解する上で必須であり，現在，最も， 精力的に研究が進められている一分野である. 図2 示した遺伝子構造より明らかなように“D領域”は，

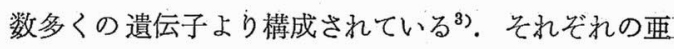

* 1984 年に 開かれた第 9 回国際ワークショップでこの 亜領域の名称を DR, DQ (旧称 DC), 枋よび DP (旧 称 SB）と呼ぶことが決定された。誁しくは文献 3をを 参照.

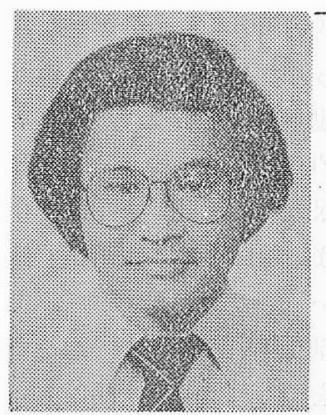

豊田裕夫 Beckman Reserch Institute of City of Hope Department of Molecular Genetics (Duarte, CA 91010 U.S.A.) Assistant Research Scientist - 医博

昭和 49 年東京薬科大大学院薬 学系修士課程修了, 53 年金沢 大大学院医学系博士課程修了. 53～56 年米国メイ $ヨ$ 一医科大, ミネンタ大細胞生物部研究員, 56 年 City of Hope 研究所分 子遗伝部入所, 57 年より現職。 
(A)

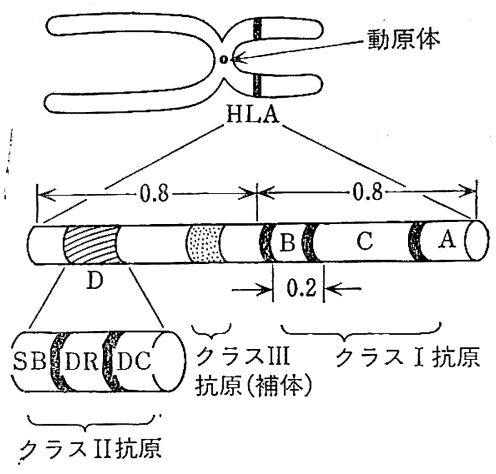

图 1 (A) \& (B) ヒトの HLA-複合体の構造
(B)

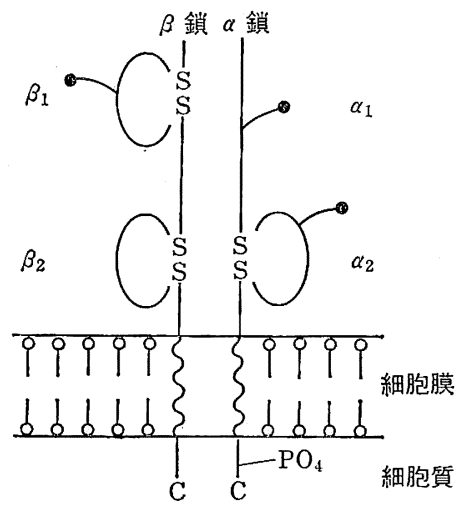

- - : 糖鎖, - S-S- : S-S 結合, $\mathrm{PO}_{4}$ : リン酸化される部位

$\mathrm{D}$ 領域の遗伝子構造の複雑性 （5つの $\alpha$ 鎖をコードする遺伝 子, 7 つの $\beta$ 鎖㕝コードする遗 伝子)は,括そらく各個人で異な ると推定される.したがって， 異なったハプロタイプをもつ場 合, $\alpha$ 鎖， $\beta$ 鎖をコードする遺 伝子の数は異なると考克られる.

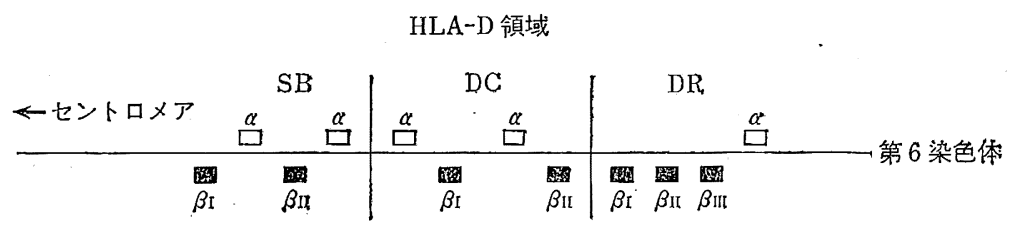

図 2 HLA-D 領域の遗伝子構造

領域よりコードされる遺伝子産物の解析から興味ある 事実が解明された。すなわち DC 亜領域の $\alpha$ 鎖を除 き, $\mathrm{DR}$ 特よび $\mathrm{SB}$ 亜領域の $\alpha$ 鎖は注とんぞ多型性 (polymorphism)*1 を示さない, 一方, ずへての亜領 域よりコードされる $\beta$ 鎖は, 多型性を示すということ である。また，DNA 塩基配列の解析から，各亜領域 よりコードされる $\beta$ 鎖間の塩基配列は，高い相同性 (70〜75\%) を示すこともわかっている2).

このように，“D領域”は，ぞのようにそれぞれの $\alpha$ 鎖， $\beta$ 鎖の遺伝子発現が制御されているのか？とい った，遺伝子構造の面からの興味ばかりでなく，臨床 上から非常に興味ある領域である. 特に, 多くの自己 免疫疾患と, ある特定の DR ハプロタイプ（haplotype)*2 との間で, 強い相関性が認められている.た とえば,インスリン依疜性の䌅尿病 (IDDM：Insulin

*1 多型性 (polymorphism) とは, あるタンパク質をコー ドする遗伝子が 1 つではなく，多数の対立遺伝子より成 ることをいう。

*2 ハプロタイプ: 血清学的特異性により各領域が細分化さ れている.たとえば, DR 亜領域の場合，16 の巽なっ た特異性があり，DC 亜領域の場合は 3 つ, SB 亜領域 の場合は 6 つである. 1つの特哄性は父方より，もう 1 つは母方より受け継ぎ，両者が同じ場合は homozygous (ホモ接合型)，異なる場合は heterozygous (ヘテロ接 合型）とそれぞれ呼ばれている，したがって，各人，各 ィ一種のハプロタイプしかもっていない. 表記法として は，たと党ば, HLA A 1,2; B 5,7; Cw 1, w 3 ; Dw 2, w 3 ; DR 3,4 などと表わされる.
Dependent Diabetes Mellitus) の場合, DR 3, DR:4 と強く相関していることが知られている.

したがって，“D領域”の遗伝子構造を詳細に解析 することにより，この領域と相関した，特定の聅患の 素因を遺伝子レベルで解析することる可能である.

2-2. DR 亜領域の $\alpha$ 鎖, $\beta$ 鎖のクローニング4) 6) 実際にどのような過程を経て，特定の遺伝子をク口 ーニングするのか，DR 韲領域の $\alpha$ 鎖， $\beta$ 鎖を例にと り説明する.

従来の遺伝子クローニングの手法に和いては， ず，目的とするタンパク質をコードする mRNAを， 精製・濃縮するにあたり，免疫学的手法（モノクロー ナル抗体など)を用いてきた，このため，目的とする タンパク質の細胞内存在量が少量の場合は，大きな困 難を伴うことになる。

このよらな問題を解決する方法として，この数年 来, 脚光をあびてきているのが，化学的に合成した DNA をプローブとして, cDNA ライブラリー*3 の中

*3 cDNA ライブラリー：細胞または臟器より mRNA を単離しこれに相補的な DNA (cDNA： complementary DNA) を作製し，ベクターと呼ばれるプラス ミドに組み込み，形質転換法を用いて，大腸菌に挿入す

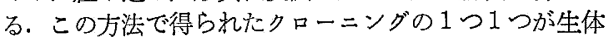
内に存在する，異なる mRNA 分子 $(10,000 \sim 30,000$ 分子と推定される) を代表する.このよらな生体内のす ベての mRNA 分子の情報を含む cDNA 分子の集ま りを cDNA ライブラリーと呼ぶ. 
表 1 HLA-DR $\alpha$ 鎖 $\mathrm{N}$ 末端のアミノ酸配列と使用した合成プロープ

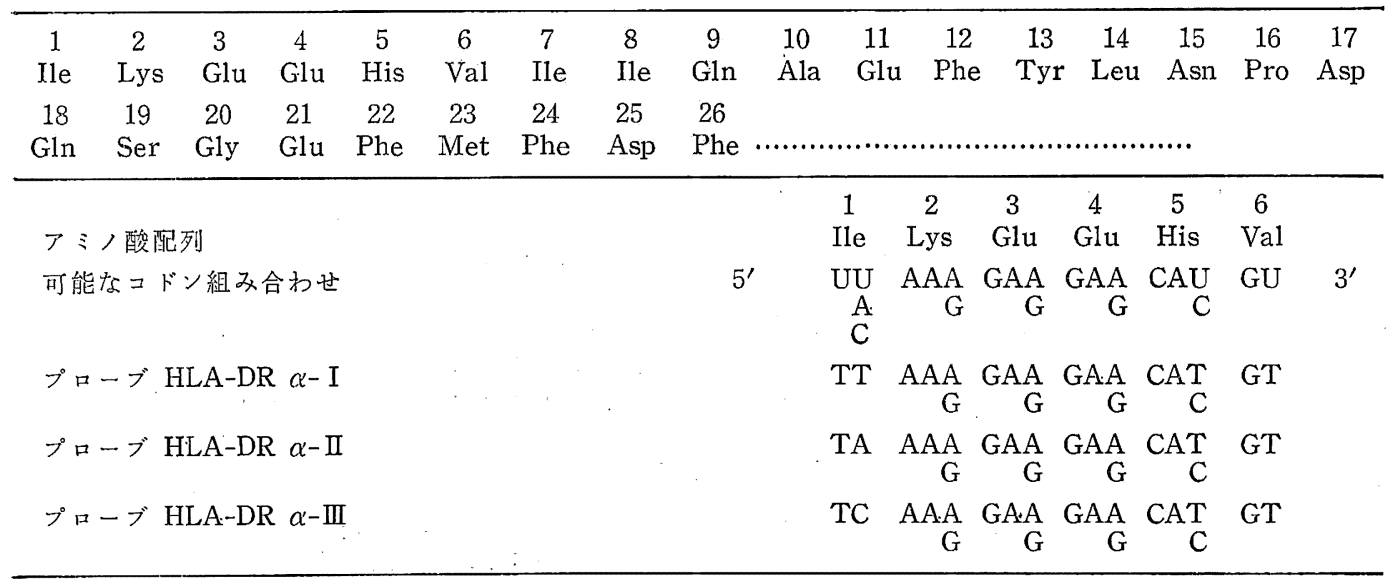

から目的とする遺伝子をクローニングする方法であ る.この方法は, 途中 mRNAを漲縮することなく, ネクリーニングできるのが大きな利点である.

しかし，この方法を用いる場合は，目的とするタン パク質の部分的アミノ酸配列がわからなけれぱ，プロ ーブを合成することができない，生体内に微量しか存 在しないタンパク質のアミノ酸配列の同定は最近開発 された“微量アミノ酸配列決定法”》を用いることに よって可能になった. 現在, 約 $10 \mu \mathrm{g}$ 以上の精製タン パク質があれば，そのN末端部分的アミノ酸配列を決 定することが可能である。

タンパク質を構成する 20 種のアミノ酸は，それぞ れ，3つの塩留（コドン）の組み合わせとより規定さ れている、たと究ば、トリプトファン、メチオニンを 規定する塩基の組み合わせは，1種類しかなく，それ ぞれ UGG, AUGである。一方, 他のアミノ酸の場合 には, 縮重 (degeneracy) が認められ，たとえばロイ シンの場合には， 6 種類の組み合わせがある。ところ が生体は，1種類の組み合わせしか用いていない。ど の䋎み合わせを，生体が使用しているかは，得られた クローニングの DNA 塩基配列を決定して初わて明ら かとなる. したがって, 合成したプローブは, プロー ブ部位のアミノ酸配列を規定する，すべての塩基配列 の組み合わせを含んでいる混成プローブ（mix-probe 法) *1 である.

$\mathrm{DR}$ 西領域の $\alpha$ 鎖の $\mathrm{N}$ 末端部分アミノ酸配列を決

*1 混成プローブ (mix-probe) を作貲する際に問題となる のは (1) プローブの長さと (2) プローブ部位の選び方で ある、(11に関しては，短かすぎると，プローブの特異性 が低くなり，長すぎると，組み合わせの数が多くなる. 实際には，17〜19 程基を用いてスクリーニングを行な っている. (2)に関しては, できるだけ縮重度の少ない部 位を選ぶことが重要である.
めるために使用したプローブの種類を表 1 亿示す. 48 種類の混成プローブを用いてクローニングを行な

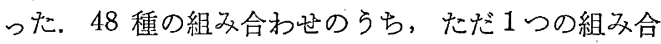
わせのみが，目的とするクローニングと完全隹相補的 な塩基配列から構成され，このプローブ以外は，目的 とするクローニングの塩基配列と，少なくとも 1 力所 以上塩基配列が異なる. 塩基対が完全飞相補的な場合 と非相補的塩基対が 1 力所以上ある場合（ミスマッチ を含さ場合）の䓡安定性には差があるため，両者を ある特定の条件下*2で識別することができる，上述し た方法により，スクリーニングした結果，プローブ HLA-DR $\alpha_{\alpha}$ III と強くハイブリダイズし，他の 2 つの プローブとは, 弱くハイブリダイズするクローニング を得た。さら詳しく解析した結果, プローブ部位の 塩基配列は

$$
\text { 一T CAAAGAAGAACA TGT- }
$$

であることを確認した．一方，DR 亚領域の $\beta$ 鎖遺伝 子はすでに述べたように，多型性でありしかも互いに 塩基配列の相同性が高いため, 混成プローブではクロ ーニングが困難で㟧り, 単一プローブで, かつ 40 塩 基前後の長い合成プローブを用いてクローニングを行 なった，長いプローブの利点は，プローブと目的とす るクローニング DNA 間で, 非相補的な塩基配列があ って子塩基対形成が可能なことである，40塩基前後 では $2 \sim 3$ 塩基, 50 塩基前後では数塩基の非相補が あっても，塩基対を形成する，この方法を用いて種及 のヒトの成長因子がクローニング9,10)されている.

*2 $T_{\mathrm{d}}=2 \times(\mathrm{A}+\mathrm{T})+4 \times(\mathrm{G}+\mathrm{C})$ といら経臨式8)を用い て，ハイブリダイゼーションの温度を設定している. $T_{\mathrm{d}}$ は，合成プローブ・DNA 塩基対に拈いてハイブリ ダイズしたプローブの $50 \%$ 量が解離する温度である. 
DR 亜領域に関して，ホモ接合型を 示す. Bリンパ芽球細胞より DNA を単離し，制限醉素 (Bam HI) で 切断後, D領域に特異的な合成プロ ーブを用いて，ハイブリダイゼーシ ョンを行なった.

番号は, DR のハプロタイプを示 す. 矢印はマーカーを示す $(\lambda \mathrm{DNA}$ の Hae III ダイジェストを用いた).

図 3 D 領域の DNA タイピング

\section{3. 遺伝子工学の医学領域への応用一特に DNA タイピングについて}

“D領域”はすすでに述べたように，血清学的な手法 を用いて，数多くのハプロタイプに分類されている.

一方, 図 2 に示すように $\alpha$ 鎖, $\beta$ 鎖遺伝子のクロー二 ングが進さにつれ，“D領域”は少なくとも全部で 12 の遺伝子から構成されていることがわかってきた。で は，血清学的に異なるハプロタイプはとの遺伝子構成 も異なるのであろうか，という疑問に刘して答えるた めに考党たれれたのが “DNA タイピング”である。 特定の塩基配列を認識する醳素 (制限酵素) で, 異な るハプロタイプを示す遺伝子 DNA を切断し，ゲル電 気泳動後,クローニングした“ $\mathrm{D}$ 領域”を構成する遺 伝子 DNA をプロープとして，ハイブリダイゼーショ ンを行なら。もし，異なるハプロタイプでは，その遺 伝子の塩基配列も異なるとすれば, プローブのハイブ リダイズする位直が異なるははずである，図 3 に示した ように，異なるハプロタイプでは，ハイブリダイズす る位置の異なる DNA 断片が検出されることがわかっ た ${ }^{11)}$. 現在 “D領域” の各亚領域 (DR, DC, SB) 飞 特異的な合成プローブ11を，クローニングした $\beta$ 鎖遺 伝子の塩基配列をもとにして合成し; “DNA タイピン グ”に利用している.

この手法は, “D領域”と相関する種々の疾患を遺 伝子レベルで解析する上で有効な万法と考学られる. さらに, 合成 DNA プローブを用いて, ヒトの代表的 遺伝病の一りである政状赤血球貧血症 ${ }^{12)}$ の遗伝子レべ ルの解析も進んでいる。

\section{4. おわりに}

遺伝子工学一特に合成プローブーを用いて, “微量 生理活性物質の遺伝子をどのように単離するのか?”
また，“得られた遺伝子を用いて，どのようなことが できるのか?”，その一部を紹介した，紙面の都合で， その他多くの応用例を紹介できなかったが，興味ある 読者恃総説 ${ }^{13)}$ を参照されたい。この小文が，遺伝子工 学の有效性を理解する上で, 少しでも役立てば幸いで める。

\section{文献}

1) J. Dausset: Science, 213, 1469 (1981)

2) J.F. Kaufman, C. Auffray, A. J. Korman, D. A. Shackelford, J. Strominger: Cell, 36, 1 (1984)

3) J. Bodmer, W. Bodmer: Immunol. Today, 5, 252 (1984)

4) Y. Kajimura, H. Toyoda, M. Sato, S. Miyakoshi, S.A. Kaplan, Y. Ike, S. M. Goyert, J. Silver, P. Hawke, J. E. Shively, S. V. Suggs, R. B. Wallace, K. Itakura: DNA, 2, 175 (1983)

5) 豊田裕夫, 梶村芳堆, 板倉啓壱 : 色疫 ' 82 , 代謝, 19, 241 (1982)

6) H. Toyoda, J. Krull, S. Miyakoshi, (in preparation)

7) J. E. Shively, D. Hawke, B.N. Jones: Anal. Biochem., 120, 312 (1982)

8) R.B. Wallace, N.J. Johnson, T. Hirose, T. Miyake, E. H. Kawashima, K. Itakura: Nucleic Acids Rcs., 9, 879 (1981)

9) A. Ullrich, C. H. Berman, T.J. Dull, A. Gray, J.M. Lee: EMBO J., 3, 361 (1984)

10) R. Dergnck, A. Roberts, M.E. Winkler, E. Y. Chem, D. V. Goeddel: Cell, 38, 287 (1984)

11) H. Toyoda, J. Krull, S. Miyakoshi, K. Itakura, L. Fisher: Proc. Natl. Acad. Sci. U.S.A., Submitted

12) B. J. Conner, A.A. Reyes, C. Morin, K. Itakura, R. L. Teplitz, R. B. Wallace: Proc. Natl. Aced. Sci. U.S. A., 80, 278 (1983)

13) K. Itakura, J. Rossi, R. B. Wallace: Ann. Rev. Biochem., 53, 323 (1984) 